\title{
Improved detection of stage I non-small cell lung cancer with a serum-based assay
}

\author{
Bryan M. Burt, MD
}

See related article on pages 727-34.

Building on their previous experience in the field and sound scientific rationale, Kubasiak and colleagues ${ }^{1}$ retrospectively evaluated serum concentrations of insulinlike growth factor (IGF)-associated proteins in patients with pulmonary nodules who were considered high risk for development of lung cancer. Kubasiak and colleagues ${ }^{1}$ ultimately incorporated their findings into the refinement of a multianalyte serum-based assay to be used as a companion test in conjunction with lung cancer screening by low-dose computed tomography (LDCT) (Figure 1); their study is reported in this issue of the Journal.

The importance of this study lies with the high negative predictive value of the described assay $(100 \%$ in their validation cohort) and its implications for LDCT screening. The National Lung Screening Trial (NSLT) reported that annual screening for 3 years with low-dose helical computed tomography in patients at high risk for lung cancer was associated with a $20 \%$ relative reduction in lung cancer mortality. ${ }^{2}$ A major challenge in implementing LDCT screening is the high frequency of false-positive results, thus exposing individuals to unnecessary and potentially hazardous diagnostic evaluations as well as to psychologic tension. In the NSLT, for example, $24.2 \%$ of screening LDCT scans were positive for nodules, but $96.4 \%$ of these nodules were determined to be falsely positive. According to the current NSLT inclusion criteria for LDCT screening, approximately 7 million individuals would qualify for screening in the United States, and therefore upward of 1.6 million of these persons would be found to have indeterminate nodules that might require diagnostic or surgical intervention. ${ }^{2}$

Kubasiak and colleagues ${ }^{1}$ have used elegant methodology to construct and validate a 7-analyte panel incorporating measurements of serum interleukin 6, interleukin 10, interleukin 1 receptor antagonist, stromal cell-derived

\footnotetext{
From the Division of Thoracic Surgery, Department of Surgery, Baylor College of Medicine, Houston, Tex.

Disclosures: Author has nothing to disclose with regard to commercial support.

Received for publication Nov 23, 2014; accepted for publication Nov 24, 2014; available ahead of print Jan 15, 2015.

Address for reprints: Bryan M. Burt, MD, Division of Thoracic Surgery, Department of Surgery, Baylor College of Medicine, Houston, TX 77005 (E-mail: bryan.burt@ bem.edu).

J Thorac Cardiovasc Surg 2015;149:735-6

$0022-5223 / \$ 36.00$

Copyright (c) 2015 by The American Association for Thoracic Surgery http://dx.doi.org/10.1016/j.jtcvs.2014.11.071
}

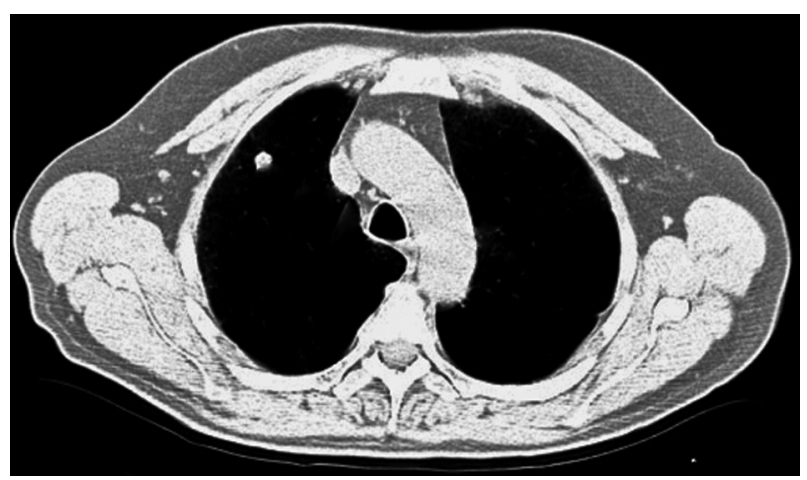

FIGURE 1. Nodule detection by low-dose computed tomographic scan

factor $1 \alpha$ and $1 \beta$, IGF binding protein 4 , IGF binding protein 5, and IGF-2. This panel had negative predictive values of $89 \%$ to $100 \%$ in their test and validation groups, respectively. Such a highly performing and inexpensive test is of particular value for individuals with indeterminate nodules found by LDCT screening protocols; it could potentially reduce the rate of false positives from computed tomographic screening and ultimately decrease the diagnostic burden and morbidity and mortality resultant from the workup of indeterminate nodules. The need for such blood-based assays as companions to LDCT is reflected in a position statement by the International Association for the Study of Lung Cancer and its Strategic CT Screening Advisory Committee, which recognized the need for further work in blood-based biomarkers as an adjunct to LDCT to mitigate the high rates of false positivity.

Although the study was retrospective in nature, Kubasiak and colleagues ${ }^{1}$ used an independent cohort of patients from a separate institution as a validation arm. The principal weaknesses of this study are the relatively small numbers of patients in their individual study cohorts and the study's retrospective design. For example, the validation cohort for the multianalyte test included only 20 patients with lung cancer. It should also be noted that the criteria used by Kubasiak and colleagues ${ }^{1}$ to define a high-risk cohort were an age greater than 50 years and a smoking history greater than 20 pack-years, which is a more permissive standard than that used in the NSLT (age $\geq 55$ years with $\mathrm{a} \geq 30$-pack-year smoking history) and therefore represents individuals with more moderate risk of lung cancer than those studied in the NSLT.

More recently, a grade $\mathrm{B}$ recommendation for computed tomographic screening in high-risk groups by the US Preventative Services Task Force has fueled pressure for 
national insurance coverage of lung cancer screening with LDCT. ${ }^{4}$ In contrast, the Medicare Evidence Development and Coverage Advisory Committee concluded that the apparent benefits of LDCT screening did not clearly outweigh its attendant harms among Medicare beneficiaries, and the Centers for Medicare and Medicaid Services decision regarding coverage of LDCT screening is expected in 2015. Clearly, the adoption of well validated and highly performing adjunctive tests that decrease the risk associated with computed tomographic screening would be expected to favorably impact the availability of LDCT screening to the public.

In summary, Kubasiak and colleagues ${ }^{1}$ have constructed a serum-based assay with a high negative predictive value for differentiating malignant from benign lung lesions on chest computed tomography. Advantageous features of this test include its ease of use and its low expense. The true benefit of this assay as a part of lung cancer screening will only be defined by prospective implementation of such an assay in a screening program based on LDCT.

\section{References}

1. Kubasiak JC, Seder CW, Pithadia R, Basu S, Fhied C, Phillips WM, et al. value of circulating insulin-like growth factor-associated proteins for the detection of stage I non-small cell lung cancer. J Thorac Cardiovasc Surg. 2015;149: 727-34.

2. National Lung Screening Trial Research Team, Aberle DR, Adams AM, Berg CD, Black WC, Clapp JD, et al. Reduced lung-cancer mortality with low-dose computed tomographic screening. N Engl J Med. 2011;365: 395-409.

3. Field JK, Smith RA, Aberle DR, Oudkerk M, Baldwin DR, Yankelevitz D, et al. International Association for the Study of Lung Cancer Computed Tomography Screening Workshop 2011 report. J Thorac Oncol. 2012;7: 10-9.

4. Centers for Medicare \& Medicaid Services [Internet]. Baltimore: The Centers; c1998- [cited 2014 Nov 23]. MEDCAC Meeting 4/30/2014-Lung Cancer Screening with Low Dose Computed Tomography; [about 13 screens]. Available from: http://www.cms.gov/medicare-coverage-database/details/medcac-meetingdetails.aspx?MEDCACId $=68$

Readers who found these articles interesting may also like to read the following papers found in recent and future issues of our sister publications, Seminars in Thoracic and Cardiovascular Surgery and Operative Techniques in Thoracic and Cardiovascular Surgery!

News and Views: Marc de Perrot. Novel induction therapies for pleural mesothelioma. Semin Thorac Cardiovasc Surg. Autumn 2014;26(3):192-200.

State of the Art: Yolonda Colson. Current Innovations in Sentinel Lymph Node Mapping for the Staging and Treatment of Resectable Lung Cancer. Semin Thorac Cardiovasc Surg. Autumn 2014;26(3):201-209.

State of the Art: Prasad Adusumilli. The IASLC/ATS/ERS Lung Adenocarcinoma Classification: What the surgeon should know. Semin Thorac Cardiovasc Surg. Autumn 2014;26(3):210-222.

Current Readings: Robert Suh. Percutaneous Ablation for Pulmonary Metastatic Disease. Semin Thorac Cardiovasc Surg. Autumn 2014;26(3):239-248.

Current Readings: Anne Tsao. Window-of-Opportunity Trials for Thoracic Malignancies. Semin Thorac Cardiovasc Surg. Expected publication April 2015.

State of the Art: Isabelle Schmitt-Opitz. Induction Therapy for Mesothelioma. Semin Thorac Cardiovasc Surg. Expected publication August 2015.

State of the Art: David Schrump. Precision Therapy for Lung Cancer: Tyrosine Kinase Inhibitors and Beyond. Semin Thorac Cardiovasc Surg. Expected publication August 2015. 